\title{
Bioanalytical Method Development and Validation for Simultaneous Estimation of Paracetamol and Cefixime by using RP-HPLC in Rabbit Plasma
}

\author{
G. RAVEENDRA BABU ${ }^{1}$, A. LAKSHMANA RAO ${ }^{2 *}$ and J. VENKATESWARA RAO ${ }^{3}$
}

${ }^{1}$ A.K.R.G. College of Pharmacy, Nallajerla - 534112, India.

${ }^{2}$ V.V. Institute of Pharmaceutical Sciences, Gudlavalleru - 521356, India.

${ }^{3}$ Bharat School of Pharmacy, Mangalpalli - 501510, India.

*Corresponding author E-mail: dralrao@gmail.com

http://dx.doi.org/10.13005/ojc/320178

(Received: November 17, 2015; Accepted: February 24, 2016)

\begin{abstract}
A novel approach was used to develop and validate a bioanalytical RP-HPLC method for the simultaneous estimation of Paracetamol and Cefixime in rabbit plasma using Cefaclor as internal standard. Evaluation of the content of drugs were done by employing a mixture of Phosphate buffer $\left(p^{H} 6.4\right)$ and Acetonitrile $(80: 20, v / v)$ as the mobile phase and measure the absorbance at $245 \mathrm{~nm}$ for Paracetamol and Cefixime. Retention time was established to be $3.618 \mathrm{~min}$ for Cefaclor, 4.608 min for Paracetamol and 5.914min for Cefixime. The results shown that the analytical technique furnished here establishes acceptable accuracy and precision, shorter and easy sample preparation, reduced the complications for equipment on satisfactory analysis time.
\end{abstract}

Key words: Paracetamol, Cefixime, Bioanalytical, Simultaneous, Development.

\section{INTRODUCTION}

Paracetamol (Figure 1) is chemically $\mathrm{N}$-(4-hydoxyphenyl) ethanamide and it was a nonsteroidal anti-inflammatory drug having potent antipyretic, analgesic and anti-inflammatory action $^{1-2}$. Paracetamol was used for the pains and high temperature fevers ${ }^{3}$. Paracetamol acts by selectively inhibiting the prostaglandin biosynthesis. The bioavailability of the Paracetamol was $80 \%{ }^{4}$.
Cefixime (Figure 2) is chemically (6R,7R)-7-((2-(2-amino-1,3-thiazol-4-yl)-2(carboxymethoxyimino)acetyl)amino)-3-ethenyl8-oxo-5-thia-1-azabicyclo(4.2.0)octo-2-ene-2carboxylic acid and it was a third generation cephalosporin antibiotic used for the several bacterial infections ${ }^{5-6}$. Cefixime acts by binding to specific penicillin binding protein leads to inhibiting bacterial cell wall synthesis and the bioavailability was $40 \%$ to $50 \%{ }^{7}$. 


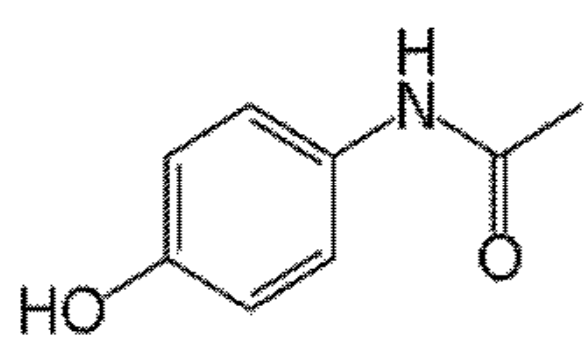

Fig. 1: Structure of Paracetamol

Cefaclor (Figure 3) is chemically 3-chloro7-D-(2-phenylglycinamido)-3-cephem-4-carboxylic acid monohydrate and it was a semisynthetic cephalosporin antibiotic for oral administration. Cefaclor is used to reduce the development of drugresistant bacteria.

Literature survey revealed that few analytical methods have been reported for estimation of Paracetamol and Cefixime individually or in combination with other drugs. The reported methods are Spectrophotometric ${ }^{8-10}$, HPLC $^{11-14}$, HPTLC $^{15-16}$ and LC-MS ${ }^{17-18}$. Although no method was reported for the simultaneous estimation of Paracetamol and Cefixime in combined pharmaceutical formulations.

The present study was aimed to develop a simple, sensitive, rapid, precise and accurate and validated the bionalytical method ${ }^{19}$ for simultaneous estimation of Paracetamol and Cefixime according to $\mathrm{ICH}$ guideline $\mathrm{s}^{20}$ by using high performance liquid chromatography in rabbit plasma.

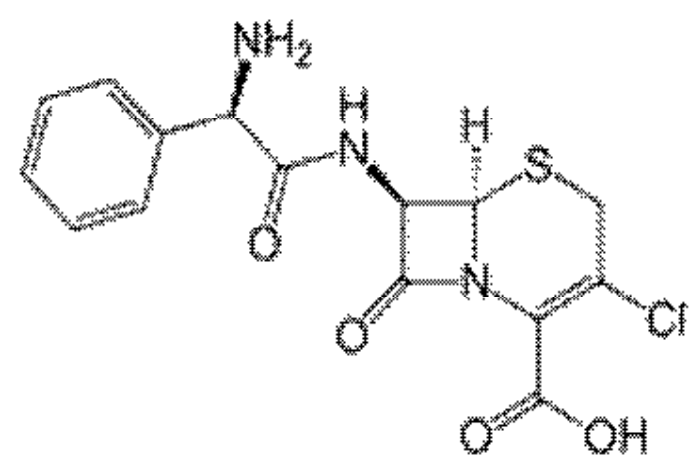

Fig. 3: Structure of Cefaclor<smiles>C=CC1=C(C(=O)O)N2C(=O)[C@@H](NC(=O)/C(=N/OCC(=O)O)c3csc(N)n3)[C@H]2SC1</smiles>

Fig. 2: Structure of Cefixime

\section{EXPERIMENTAL}

Chemicals, reagents, standards and samples Blank rabbit plasma, pure samples of drugs like Paracetamol, Cefixime and Cefaclor was obtained from Spectrum Pharma Research Solutions, Hyderabad, India. Analytical grade of Orthophosporic acid was obtained from SD Fine Chemicals Ltd., Mumbai, India. HPLC grade of Acetonitrile and Water was obtained from Qualigens Fine Chemicals, Mumbai, India.

\section{Instrumentation}

The analysis was performed by using a chromatographic system Water 2695 series HPLC comprised of vacuum degas, auto injector, dual gradient pump with photo diode array detector. The HPLC system was equipped with Empower 2 software.

\section{Chromatographic conditions}

Paracetamol and Cefixime was analysed in ODS C18 column $(250 \mathrm{mmx} 4.6 \mathrm{~mm}, 5 \mu \mathrm{m}$ particle size) for the chromatographic separation. The mobile phase was composed of Phosphate buffer $\left(p^{H} 6.4\right)$ and Acetonitrile (80:20, v/v) and was used as diluent. Filtered through $0.45 \mu \mathrm{m}$ nylon membrane filter under vacuum filtration and pumped at a temperature of $30^{\circ} \mathrm{C}$, at flow rate of $1 \mathrm{ml} / \mathrm{min}$ with UV detection wavelength at $245 \mathrm{~nm}$. Injection volume was $10 \mu \mathrm{l}$. The run time was $8 \mathrm{~min}$ and the retention time of Paracetamol and Cefixime was found to be $4.608 \mathrm{~min}$ and 5.914min respectvily.

\section{Preparation of stock solutions}

Primary stock solutions of Paracetamol and Cefixime were prepared individually by dissolving 
$10 \mathrm{mg}$ of each in $25 \mathrm{ml}$ volumetric flask in diluent. Series of working solutions of Paracetamol and Cefixime were prepared by the suitable dilution of the stock solutions with same diluent to achieve the concentration range of $10-100 \mu \mathrm{g} / \mathrm{ml}$ for Paracetamol and $5-50 \mu \mathrm{g} / \mathrm{ml}$ for Cefixime.

\section{Procedure}

The standard solutions were prepared by dilution of the stock solution with diluent to obtain a concentration range $10-100 \mu \mathrm{g} / \mathrm{ml}$ for Paracetamol and $5-50 \mu \mathrm{g} / \mathrm{ml}$ for Cefixime. Triplicate of $10 \mu \mathrm{l}$ injections were prepared for each concentration and chromatographed under the conditions reported above. The peak area of each concentration was plotted against the corresponding concentration for getting the calibration curve and the regression equation was computed.

\section{Preparation of spiked plasma sample}

$250 \mu$ l of rabbit plasma, $50 \mu$ l of internal standard, $10 \mu$ l of Paracetamol and $10 \mu$ l of Cefixime

Table 1: Precision and accuracy

\begin{tabular}{lcccccccc}
\hline $\begin{array}{l}\text { Within } \\
\text { batch }\end{array}$ & $\begin{array}{c}\text { LLOQ } \\
\text { QC } \\
\text { Paracet- } \\
\text { amol }\end{array}$ & Cefixime & $\begin{array}{c}\text { LQC } \\
\text { Paracet- } \\
\text { amol }\end{array}$ & Cefixime & $\begin{array}{c}\text { MQC } \\
\text { Paracet- } \\
\text { amol }\end{array}$ & & $\begin{array}{c}\text { HQC } \\
\text { Cefixime } \\
\text { Paracet- } \\
\text { amol }\end{array}$ & \\
\hline Mean & 106 & 105.67 & 103.65 & 96 & 100.37 & 96.33 & 96.33 & 102.67 \\
S.D (+/-) & 0.013 & 0.008 & 0.05 & 0.006 & 0.089 & 0.037 & 0.037 & 0.053 \\
C.V (\%) & 6.21 & 3.16 & 8.05 & 3.16 & 8.96 & 7.73 & 7.73 & 5.80 \\
\hline
\end{tabular}

Table 2: Recovery studies

\begin{tabular}{lccc}
\hline & Paracetamol & Cefixime & Cefaclor \\
\hline Mean & 50.63 & 51.74 & 57.20 \\
S.D (+/-) & 1.98 & 1.42 & 0.509 \\
C.V (\%) & 3.93 & 2.75 & 8.17 \\
\hline
\end{tabular}

were pipetted into $10 \mathrm{ml}$ centrifuge tube and to it $2 \mathrm{ml}$ of Acetonitrile was added. The mixture was mixed shortly, standing for $5 \mathrm{~min}$ at room temperature, then vortex for $3 \mathrm{~min}$, finally the mixture was centrifuged at $3200 \mathrm{rpm}$ for $10 \mathrm{~min}$. After the centrifugation, $10 \mu \mathrm{l}$ of the supernantant layer was collected and injected into HPLC.

Table 3: Long term stability studies

\begin{tabular}{lcccc}
\hline & \multicolumn{2}{c}{ LQC } & \multicolumn{2}{c}{ HQC } \\
& Paracetamol & Cefixime & Paracetamol & Cefixime \\
\hline Mean & 99.27 & 98.71 & 104.86 & 93.08 \\
S.D (+/-) & 0.049 & 0.018 & 0.170 & 0.085 \\
C.V (\%) & 8.41 & 8.82 & 9.09 & 9.63 \\
\hline
\end{tabular}

Table 4: Freeze-thaw stability studies

\begin{tabular}{lcccc}
\hline & \multicolumn{2}{c}{ LQC } & \multicolumn{2}{c}{ HQC } \\
& Paracetamol & Cefixime & Paracetamol & Cefixime \\
\hline Mean & 104.8 & 104.6 & 97.83 & 100.97 \\
S.D (+/-) & 0.035 & 0.012 & 0.185 & 0.056 \\
C.V (\%) & 5.57 & 6.19 & 9.84 & 5.83 \\
\hline
\end{tabular}




\section{Calibration and linearity}

Calibration curves were plotted in the concentration range of $10-100 \mu \mathrm{g} / \mathrm{ml}$ and $5-50 \mu \mathrm{g} /$ $\mathrm{ml}$ for Paracetamol and Cefixime respectively of required concentrations in the measured samples. Triplicate of 10 $\mu \mathrm{l}$ injections were constructed for each working standard solution. The peak area for each concentration was measured and subsequently to draw against the each concentration to obtain the calibration curve.

\section{Method validation Linearity}

Calibration curves showed the relation between the concentrations of drugs versus peak area were established. Results manifest linear relationship in the range of $10-100 \mu \mathrm{g} / \mathrm{ml}$ and $5-50 \mu \mathrm{g} /$ $\mathrm{ml}$ for Paracetamol and Cefixime. In two drugs run from which linear regression equation was measured by following $\mathrm{ICH}$ guidelines shown in Figure 4 and Figure 5.

\section{Precision and accuracy}

Results from the validation data from rabbit plasma were within the acceptable limits. Within batch precision method was measured to range from 6.21 to $8.96 \%$ for Paracetamol and 3.16 to $7.73 \%$ for Cefixime. The accuracy of the method was measured in the range of 96.33 to $106.0 \%$ for Paracetamol and 96.00 to $105.67 \%$ for Cefixime shown in Table 1.

\section{Recovery}

The analyte recovery for the Paracetamol and Cefixime were measured to be $50.63 \%$ and $51.74 \%$ respectively. The internal standard for Cefaclor was found to $57.20 \%$ shown in Table 2 .

\section{Stability studies \\ Long term stability}

The concentration of sample of stability ranged between 99.27 to $104.86 \%$ for Paracetamol and 93.08 to $98.71 \%$ for Cefixime of the utility value shown in Table 3.

\section{Freeze-thaw stability}

The sample concentration of freeze-thaw stability was measured to be 97.83 to $104.83 \%$ for Paracetamol and 100.97 to $104.60 \%$ for Cefixime of utility concentraton showing the stability of the drug above three freeze-thaw cycles shown in Table 4.

\section{Bench top stability}

The drug was developed to be stable for at least 4 hours on bench top at room temperature. The freshly spiked calibration standards against back calculated concentration was within a range of 94.02

Table 5: Bench top stability studies

\begin{tabular}{lcccc}
\hline & \multicolumn{2}{c}{ LQC } & \multicolumn{2}{c}{ HQC } \\
& Paracetamol & Cefixime & Paracetamol & Cefixime \\
\hline Mean & 107.54 & 103.54 & 94.02 & 88.92 \\
S.D (+/-) & 0.0143 & 0.062 & 0.009 & 0.169 \\
C.V $(\%)$ & 6.91 & 10.36 & 10.40 & 9.97 \\
\hline
\end{tabular}

Table 6: Sample studies

\begin{tabular}{lcccc}
\hline & \multicolumn{2}{c}{ LQC } & \multicolumn{2}{c}{ HQC } \\
& Paracetamol & Cefixime & Paracetamol & Cefixime \\
\hline Mean & 99.46 & 98.73 & 99.94 & 101.38 \\
S.D (+/-) & 0.018 & 0.018 & 0.994 & 0.958 \\
N & 3 & 3 & 3 & 3 \\
\hline
\end{tabular}


to $107.54 \%$ for Paracetamol and 88.92 to $103.54 \%$ for Cefixime of the utility concentration shown in Table 5.

\section{Sample stability}

The concentration of sample of stability was measured range of 99.46 to $99.94 \%$ at $2-8^{\circ} \mathrm{C}$ and 98.73 to $101.38 \%$ at room temperature for Paracetamol and Cefixime, respectively shown in Table 6.

\section{REULTS AND DISCUSSION}

Different stationary phases were tried with various columns, poor and bend peakes were

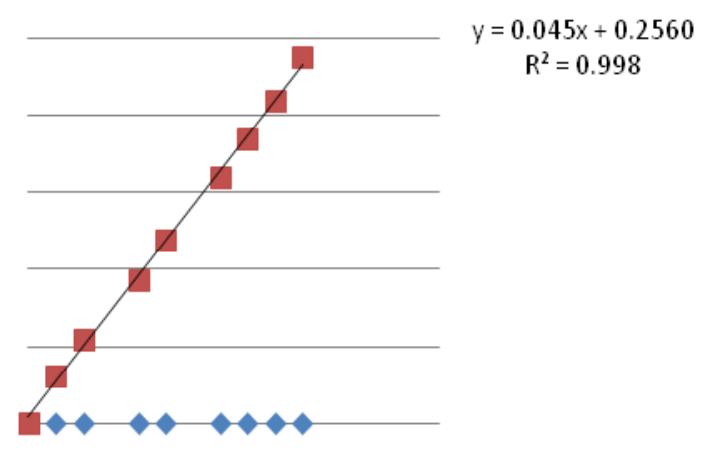

Fig. 4: Calibration curve of Paracetamol observed with different columns while C18 column gave satisfactory resolution and free from tailing. Several mobile phases used like Methanol with Acetonitrile were found to separate the compounds doubtful and Potassium dihydrogen phosphate buffer with Acetonitrile lead to good separation. The present study objective was acquired using mobile phase be composed of Phosphate buffer:Acetonitrile in the ratio of $80: 20, v / v$ with the $\mathrm{p}^{\mathrm{H}}$ adjusted to $6.4 \pm 0.2$ with Orthophosphoric acid. The mobile phase composition is optimized under described conditions, free from tailing, peaks are well defined, resolved, the tailing factors were $<2$ for all peaks. The retension times

$$
\begin{gathered}
y=0.176 x+0.0125 \\
R^{2}=0.998
\end{gathered}
$$

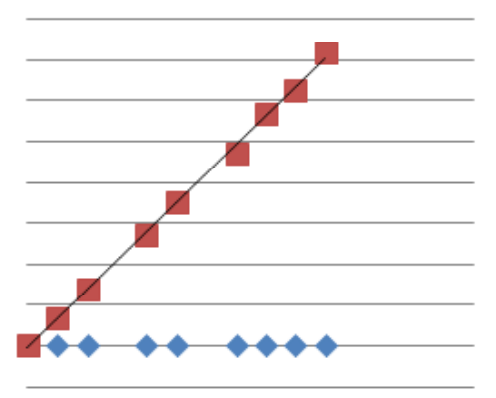

Fig. 5: Calibration curve of Cefixime

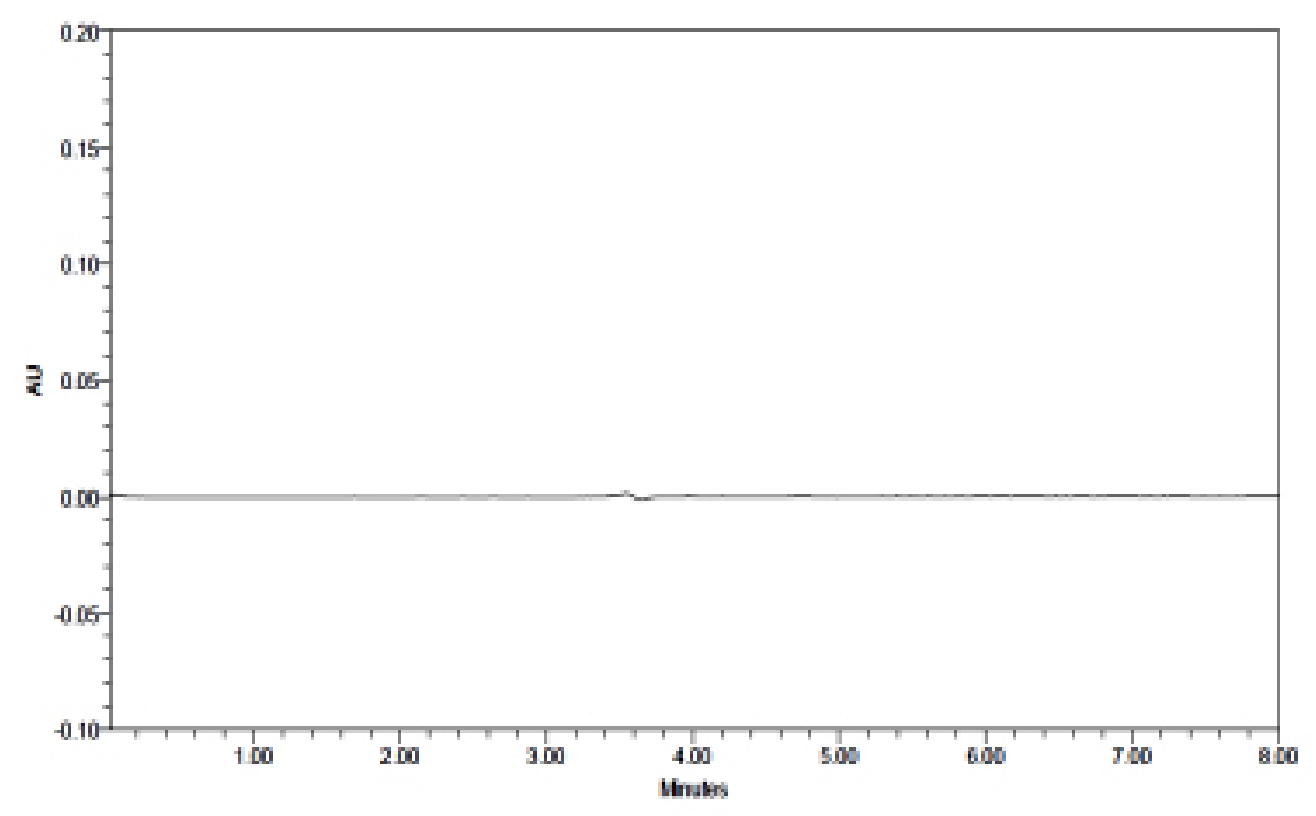

Fig. 6: Chromatogram of rabbit plasma blank 


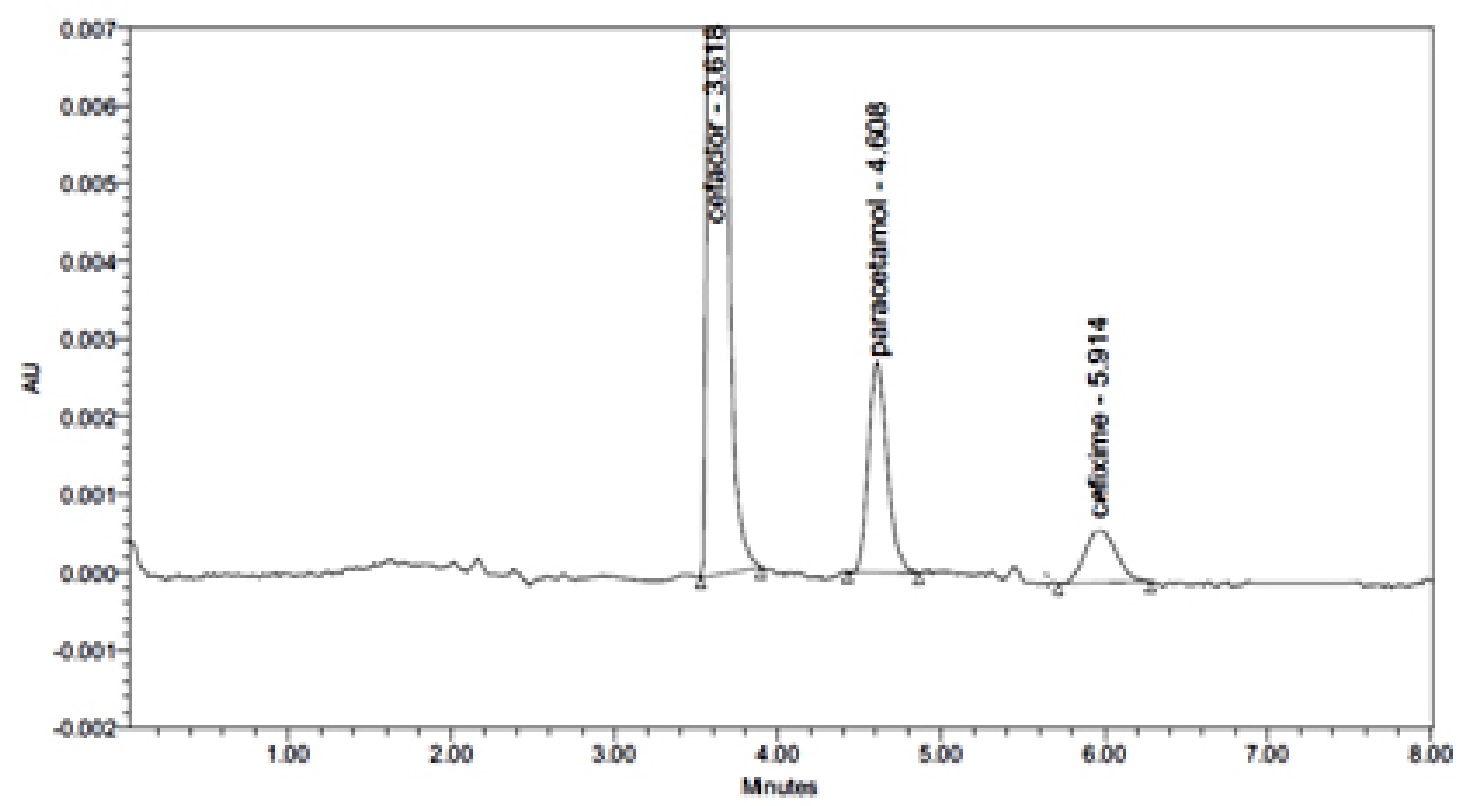

Fig. 7: Chromatogram of Cefaclor, Paracetamol and Cefixime in spiked rabbit plasma

for Paracetamol was 4.608min and for Cefixime was $5.914 \mathrm{~min}$ respectvily, at flow rate of $1 \mathrm{ml} / \mathrm{min}$. The optimum wavelength for detection was $245 \mathrm{~nm}$ at where much better detector responses for the two drugs were obtained. The chromatograms of rabbit plasma blank and drugs Cefaclor, Paracetamol and Cefixime were shown in Figure 6 \& 7 respectively.

\section{ACKNOWLEDGEMENTS}

The authors are thankful to A.K.R.G. College of Pharmacy, Nallajerla, India for providing necessary facilities for carryout the research work. The authors are thankful to Spectrum Pharma Research solutions, Hyderabad, India for providing the pure drugs like Paracetamol, Cefixime and Cefaclor.

\section{REFERENCES}

1. British National Formulary, British Medical Association and Royal Pharmaceutical Society, Joint Formulary Committee, London. 2015, 66.

2. Ayoub, S.S.; Botting, R.M.; Goorth, S.; Willoughby, D.A. Proc. Nati. Acad. Sci., 2014, 101, 11165-11169.

3. Hinz, B.; Cheremina, B.O.; Brune, K. FASEB J. 2007, 22, 383-390.

4. Smilkstein, M.L.; Kanpp, G.L.; Kullig, K.W. N. Engl. J. Med., 1988, 18, 1557-1562.

5. Mcmillan, A.; Young, H. Int. J. STD. AIDS., 2007, 18, 253-254.

6. Adam, D.; Hostalek, U.; Troster K. Infection,
1995, 23 Suppl 2, S83-S86.

7. Patil, S.P.; Hajare, A.L.; Krishna, K.P. Int. J. Basic Clin. Pharmacol., 2014, 3, 943-946.

8. Behera, S.A.; Ghanty, S.; Ahmad, F.; Santra, S. J. Anal. Bioanal. Tech., 2013, 3, 2-6.

9. Sharma, S.; Pareek, A.; Joshi, R.; Yashumati, R.B.; Jain, V.; Jadon, G. Orient J. Chem., 2013, 29, 787-792.

10. Venkatesan, S.; Kannappan, N. Int. J. Pharm. Pharm. Sci., 2013, 3, 130-135.

11. Devi, T.A.P.; Setti, A.; Nallapeta, S.; Pawar, S.C.; Rao, J.V. J. Med. Allied Sci., 2013, 3, 8-14.

12. Calinescu, O.; Badea, I.A.; Vladescu, L.; 
Meltzer, V.; Pincu, E. J. Chromatogr. Sci., 2012, 50, 335-342.

13. Lalitha, K.V.; Golla, M.M.; Reddy, J.R.; Kumar, K.V.; Aliekya, A. J. Scient. Innova. Res., 2013, 2, 634-641.

14. Khandagle, K.S.; Gandhi, S.V.; Deshpande, P.B.; Gaikwad, N.V. Int. J. Pharm. Pharm. Sci., 2010, 3, 46-48.

15. Yadav, S.S.; Jagtap, A.S.; Rao, J.R. Der Pharma. Chemica, 2012, 4, 1798-1802.

16. Dhoka, M.V.; Gawande, V.T.; Joshi, P. Eurasian
J. Anal. Chem., 2013, 8, 99-106.

17. Trettin, A.; Jordan, J.; Tsikas, D. J. Chromatogr. B. Analyt. Technol. Biomed. Life Sci., 2014, 1, 177-178.

18. Meng, F.; Chen, X.; Zhong, D. J. Chromatogr. B. Analyt. Technol. Biomed. Life Sci., 2005, 819, 277-282.

19. Gaurav, T.; Ruchi, T. Pharm. Methods, 2010, 1, 25-38.

20. International Conference on Harmonization, Q2(R1), Geneva, Switzerland. 1996. 